\title{
Review \\ Relationship between Varicocele and Male Hypogonadism: A Review with Meta-Analysis
}

\author{
Giorgio Ivan Russo ${ }^{1}$, Maria Giovanna Asmundo ${ }^{1}$, Sarah Perelli ${ }^{2}$, Rosita A. Condorelli ${ }^{2}{ }^{(D}$, Aldo E. Calogero ${ }^{2}{ }^{(\mathbb{C}}$, \\ Rossella Cannarella ${ }^{2}$ and Sandro La Vignera ${ }^{2, *(D)}$ \\ 1 Urology Section, University of Catania, 95123 Catania, Italy; giorgioivan.russo@unict.it (G.I.R.); \\ mariagiovannaasmundo@gmail.com (M.G.A.) \\ 2 Department of Clinical and Experimental Medicine, University of Catania, 95123 Catania, Italy; \\ sarah.perelli@libero.it (S.P.); rosita.condorelli@unict.it (R.A.C.); acaloger@unict.it (A.E.C.); \\ rossella.cannarella@phd.unict.it (R.C.) \\ * Correspondence: sandrolavignera@unict.it; Tel.: +39-09-5378-1435
}

check for updates

Citation: Russo, G.I.; Asmundo, M.G.; Perelli, S.; Condorelli, R.A.; Calogero, A.E.; Cannarella, R.; La Vignera, S. Relationship between Varicocele and Male Hypogonadism: A Review with Meta-Analysis.

Endocrines 2022, 3, 100-106. https:// doi.org/10.3390/endocrines3010009

Academic Editors: Antonio Aversa and Antonio Brunetti

Received: 17 November 2021

Accepted: 25 February 2022

Published: 1 March 2022

Publisher's Note: MDPI stays neutral with regard to jurisdictional claims in published maps and institutional affiliations.

Copyright: (c) 2022 by the authors. Licensee MDPI, Basel, Switzerland. This article is an open access article distributed under the terms and conditions of the Creative Commons Attribution (CC BY) license (https:// creativecommons.org/licenses/by/ $4.0 /)$.

\begin{abstract}
The relationship between varicocele and hypogonadism becomes clearer everyday thanks to the most recent literature, particularly with regards to the impact of varicocele repair on serum testosterone level improvement in hypogonadal patients. We selected English articles published from 1964 to September 2021. The search terms "varicocele" and "hypogonadism" were used as filters. A total of 102 studies have been obtained. For the meta-analysis, the pooled mean differences (MDs) for continuous variables and the $\ln (\mathrm{OR})$ were used for data pooling observational studies. A total of 15 articles have been finally included: nine retrospective and six observational. Testosterone levels pre- and after surgery were reported in four studies. There was statistically significant heterogeneity in these studies $\left(\mathrm{chi}^{2}=267.09, \mathrm{I}^{2}=72 \% ; p=0.01\right)$. Mean differences of total testosterone was statistically different in men pre- and after-surgery (mean difference $=106.76$; $p<0.0001$ ). It is indeed established that altered environments caused by varicocele cause pantesticular insult, but it has not been unequivocally determined whether men with varicocele are at increased risk for the development of clinical hypogonadal symptoms.
\end{abstract}

Keywords: varicocele; testosterone levels; male hypogonadism

\section{Introduction}

Varicocele is a highly prevalent problem in reproductive medicine practice [1] defined as a dilatation of the veins of the pampiniform plexus. Varicocele has an incidence of approximately $15 \%$ among the general population [1,2]; to be more precise, $35 \%$ of men with primary infertility and $70 \%$ to $80 \%$ of men with secondary infertility suffer from this condition [3].

Nowadays there is much evidence suggesting a putative and well-established association between varicocele and a progressive and duration-dependent decline in testicular function. The exact process by which varicocele may impair male fertility potential remains unclear. However, different probable causes have been identified: elevated intrascrotal temperatures, blood reflux, oxidative stress, backflow of metabolites, seminiferous tubules hypoxia, sperm nuclear damage [4]. Moreover, several studies claim that varicocele causes a pantesticular insult that leads to a reduction of Sertoli cells activity and to an impairment of Leydig cell functions [5]. According to Dabaja et al., this unsuitable environment leads not only to Leydig cells hyperplasia and consequent apoptosis but causes also cellular disfunction characterized by reduced conversion of cholesterol precursors to testosterone [6,7]. However, there have been equivocal results concerning possible varicocele-related impaired testosterone levels, since some studies have found decreased levels, while others have shown no difference. The study conducted by Tanrikut et al. describing significantly lower serum testosterone levels in men with varicocele than in a control group of men undergoing 
vasectomy reversal [8] is noteworthy. However, until recently the effects of varicocele repair on patients who report low serum testosterone levels are still controversial.

It is also interesting to underline that the impact of varicocele on hypogonadism could be exacerbated by metabolic disorders that may be present during adolescence. In fact, in abnormal metabolic conditions, there is an increase of adipogenesis. This process is responsible for the development of insulin resistance, which in turn evolves into hyperglycemia. On the hypothalamus, hyperglycemia and the consequent high levels of TNF (tumor necrosis factor)- $\alpha$ are known to promote the decrease of kisspeptin receptor expression. The lack of activation of this receptor promotes the dysregulation of the gonadotropin-releasing hormone $(\mathrm{GnRH})$ pulse frequency, leading to luteinizing hormone (LH) secretion impairment by the pituitary. The absence of steroidogenesis stimulation by LH on Leydig cells induces testosterone deficiency $[9,10]$.

All these established mechanisms may be of crucial importance for testis function and fertility, strengthening the importance of a correct evaluation of metabolic and endocrinological function in patients with varicocele.

Thus, the aim of this review is to give a general overview about the relationship between varicocele and low testosterone levels.

\section{Materials and Methods}

We selected English articles published from 1964 to September 2021. The search terms "varicocele" and "hypogonadism" were used as filters. A total of 102 studies have been obtained.

\section{Statistical Analysis}

For the meta-analysis, the pooled mean differences (MDs) for continuous variables and the $\ln (\mathrm{OR})$ were used for data pooling observational studies. Meta-analysis was conducted to determine the MD and confidence intervals (CIs) of total testosterone pre- and after-surgery. Specifically, statistical heterogeneity was tested using the chi ${ }^{2}$ test. $\mathrm{I}^{2} \leq 50 \%$, the variation of the studies was considered to be homogenous, the fixed effect model was adopted. All $p$ values are 2-tailed and $<0.05$ was considered statistically significant. The analysis was performed using RevMan software v.5.1 (Cochrane Collaboration, Oxford, UK).

\section{Results}

A total of 15 articles [8,11-24] have been finally included: nine retrospective and six observational.

Even though initial studies exploring the possible impairment of testosterone levels in patients affected by varicocele were limited by the small cohort and selection bias, most recent reports offered higher-quality data. Nevertheless, it is difficult to confirm the direct impact of varicocele on Leydig cell function.

\subsection{Observational Studies}

According to the current literature concerning varicocele repair and its consequence on testosterone levels, fifteen out of twenty-eight studies confirm that androgen increases after surgery had been performed [26]. Three recent articles describe an important improvement of testosterone levels especially in hypogonadal men rather than in eugonadal ones [27]. Zhody et al. recruited 141 infertile men with varicocele and divided them into two groups: 103 underwent microsurgical varicocelectomy while 38 proceeded with assisted reproduction procedures. Authors registered substantial testosterone level increases in patients who belonged to group 1; moreover, the results had been reflected by elevation in IIEF scores. Therefore, they reported an increase in mean testosterone of $219.3 \pm 65.8 \mathrm{ng} / \mathrm{dL}$ preoperatively, to $358.1 \pm 94 \mathrm{ng} / \mathrm{dL} 6$ months postoperative while Sathya Srini and Belur Veerachari registered an increase from $177.2 \pm 18.44 \mathrm{ng} / \mathrm{dL}$ preoperative to $301 \pm 43 \mathrm{ng} / \mathrm{dL}$ postoperatively [20]. Instead, other studies, such as the one conducted by Abdel-Meguid, 
show that testosterone increase in eugonadals was far from as remarkable as in hypogonadal after surgery (mean change $=8.6 \mathrm{ng} / \mathrm{dL} ; 2.01 \% ; p=0.12$ ) [22]. Another interesting and recent study conducted by Ji et al. aims to prove the relationship between varicocele and hypogonadism and impaired erectile function as reflected in IIEF-5 and NPTR. Authors recruited 130 men with varicocele and 130 men as control with no significative difference in age, weight, height, smoking and drinking status. By their analysis, the authors were able to declare that an association between high grade varicocele and hypogonadism, as well as impaired erectile function and low total testosterone levels, exists [15]. In addition, a very recent study published in 2019 by Panach-Navarrete et al. aimed to study the relationship between the presence of varicocele and testosterone serum levels in adulthood but, in the end, it did not establish any interesting conclusions; in fact, they only observed that factors such as obesity and age are related to low testosterone levels [23]. In an vitro study from Weiss et al. enrolled 16 patients with sperm counts $<10$ million $/ \mathrm{mL}$ and varying degrees of unilateral or bilateral varicocele. The authors performed an in vitro technique of incubation of testicular tissue with radiolabeled precursors for evaluation of Leydig cell androgen synthesis and demonstrated that a significant suppression of in vitro testosterone formation was observed in almost 90 per cent of the patients [16].

Table 1 lists the overall characteristics of the study included.

Table 1. Characteristics of included studies.

\begin{tabular}{|c|c|c|c|c|c|}
\hline Authors & Year & Type of Study & N. of Patients & Mean Pre-Op TT & Mean Post-Op TT \\
\hline W. Hsiao et al. [11] & 2013 & Retrospective & 78 & $\begin{array}{l}248 \pm 8 \\
350 \pm 4\end{array}$ & $\begin{array}{l}357 \pm 25 \\
\text { (unilateral repair) } \\
459 \pm 15 \\
\text { (bilateral repair) }\end{array}$ \\
\hline C. Tanrikut et al. [8] & 2011 & Retrospective & 325 & $200 \pm 7$ & $454 \pm 168$ \\
\hline Y. Gat et al. [17] & 2004 & Retrospective & 83 & 348 & 497 \\
\hline S. Andò et al. [19] & 1984 & Retrospective & 108 & $416 \pm 13$ & (no repair) \\
\hline W. Hsiao et al. [18] & 2010 & Retrospective & 272 & $309 \pm 7$ & $431 \pm 170$ \\
\hline V. Sathya Srini et al. [20] & 2011 & Observational & 200 & $177 \pm 18$ & $301 \pm 43$ \\
\hline W. Zohdy et al. [21] & 2011 & Observational & 141 & $379 \pm 205.8$ & $450 \pm 170.2$ \\
\hline T. Abdel-Meguid et al. [22] & 2014 & Observational & 28 & $233.8 \pm 50.7$ & $327.5 \pm 53.2$ \\
\hline J. Panach-Navarrete et al. [23] & 2019 & Case-control & 387 & $379 \pm 206$ & $450 \pm 170$ \\
\hline \multirow[t]{3}{*}{ B. Saylam et al. [25] } & 2020 & Observational & 202 & $255 \pm 66$ & $372 \pm 134$ \\
\hline & & & & $\begin{array}{l}\text { Case-patients With } \\
\text { varicocele }\end{array}$ & $\begin{array}{l}\text { Control-patients } \\
\text { Without varicocele }\end{array}$ \\
\hline & Year & Type of Study & N. of Patients & Mean TT & Mean TT \\
\hline Pasqualini et al. [24] & 1980 & Retrospective & 17 & 582 & 542 \\
\hline J. I. Gorelick et al. [12] & 1993 & Retrospective & 1999 & $507 \pm 0.5$ & $585 \pm 0.8^{*}$ \\
\hline J. Raboch et al. [13] & 1971 & Retrospective & 839 & 581 & 1030 \\
\hline F. Freire, C. Nahoum et al. [14] & 1981 & Retrospective & 55 & $344 \pm 25$ & $439 \pm 29$ \\
\hline B. Ji, X.-b. Jin et al. [15] & 2016 & $\begin{array}{l}\text { Observational- } \\
\text { comparative }\end{array}$ & 260 & $310 \pm 179$ & $669 \pm 180$ \\
\hline D. B. Weiss et al. [16] & 1978 & $\begin{array}{l}\text { Observational, } \\
\text { in vitro }\end{array}$ & 16 & Not reported & Not reported \\
\hline
\end{tabular}

* In the study conducted by Gorelick et al. case group is composed of patients with primary infertility and hypogonadism and control group by patients with secondary infertility and hypogonadism. 
Zohdy et al. reported that the mean TT level increased significantly post-varicocelectomy (379.1 to $450.1, p<0.0001$ ) and that neither operating vein diameter nor testicular size correlated with the mean change in testosterone [21].

Finally, Saylam et al. demonstrated that mean serum total testosterone level significantly increased from 2.55 to 3.72 after varicocelectomy $(p<0.0001)$, and 105 patients $(52 \%)$ had a serum total testosterone level of $\geq 3.5 \mathrm{ng} / \mathrm{mL}$ after the surgery [25].

\subsection{Retrospective Studies}

Most of the articles selected belong to the retrospective category. Probably because initial studies exploring the possible relation between varicocele and impaired testosterone level were limited by small samples of patients, retrospective design and selection bias, the results are equivocal. A small cohort and well-fashioned study conducted by Pasqualini et al. found normal TT (Testicular Testosterone) and ST (Serum Testosterone) levels in most of the patients with varicocele involved in the study. In this 17-patient study, they concluded that even though Leydig cell function may be partially impaired in varicocele, it seems to be compensated by LH (Luteinizing Hormone) stimulation, as confirmed by normal ST concentration [24]. Contrarily, several other studies found distinctly lower plasmatic testosterone levels in all age subgroups of patients who suffer from venous disturbance than in the control group. However, no correlation between androgen plasmatic level and spermatogenic impairment or varicocele grade has been identified [13]. Freire and Nahoum confirmed the same relation [14].

Gat et al. performed a study on internal sperm vein embolization in patients with varicocele and reported that mean serum testosterone concentration rose after embolization by $43 \%$, from 12.07 to 17.22 ( $p<0.001)$ [17], and similarly Andò et al. [19] reported that mean plasma T levels were significantly decreased in varicocele patients (416) vs. control group (487), while the basal 17-OH-P/T ratio was significantly increased (0.38 vs. 0.28 ).

Gorelick and Golstein conducted an interesting study on a huge patient cross-section whose aim was to prove that men with varicocele who had already fathered children were immune to impairment of fertility. However, the review conducted on 1300 men refuted the authors' hypothesis. On the contrary, the study suggested that varicocele produces a progressive, time-dependent testicular injury [12]. This is somehow rejected by Hsiao et al. who recruited 272 men and divided them into three groups according to their age: younger than 30 years, between 30-39 years and older than 40 years. The authors concluded that varicocelectomy resulted in significant improvement in testosterone levels in all age groups providing that the patient was hypogonadal [11].

Hsiao (2013) et al. showed that the improvement of total testosterone was seen regardless of the clinical grade of varicocele and it was from 308.4 to $417.5 \mathrm{ng} / \mathrm{dL}$, with a mean increase of $109.1 \pm 12.8 \mathrm{ng} / \mathrm{dL}(\mathrm{n}=78)$ [18].

\subsection{Meta-Analysis}

Testosterone levels pre- and after surgery were reported in four studies [20-22,25]. There was statistically significant heterogeneity in these studies $\left(x^{2}=267.09, I^{2}=72 \%\right.$; $p=0.01$ ) (Figure 1).

\begin{tabular}{|c|c|c|c|c|c|c|c|c|c|c|}
\hline \multirow[b]{2}{*}{ Study or Subgroup } & \multicolumn{3}{|c|}{ Post-varicocelectomy } & \multicolumn{3}{|c|}{ Pre-Varicocelectomy } & \multicolumn{2}{|r|}{ Mean Difference } & \multirow{2}{*}{\multicolumn{2}{|c|}{$\begin{array}{c}\text { Mean Difference } \\
\text { IV, Random, } 95 \% \mathrm{CI}\end{array}$}} \\
\hline & Mean & SD & Total & Mean & SD & Total & Weight & IV, Random, 95\% CI & & \\
\hline Abdel-Meguid et al 2014 & 327.5 & 53.2 & 28 & 238.8 & 50.7 & 28 & $22.4 \%$ & $88.70[61.48,115.92]$ & & $\div$ \\
\hline Sathya Srini et al 2011 & 301 & 43 & 200 & 178 & 18 & 200 & $37.0 \%$ & $123.00[116.54,129.46]$ & & - \\
\hline Saylam et al 2020 & 372 & 134 & 202 & 255 & 66 & 202 & $27.3 \%$ & $117.00[96.40,137.60]$ & & $=$ \\
\hline Zohdy et al 2011 & 450 & 170.2 & 141 & 379 & 205.8 & 141 & $13.3 \%$ & $71.00[26.92,115.08]$ & & $\pi$ \\
\hline Total $(95 \% \mathrm{Cl})$ & & & 571 & & & 571 & $100.0 \%$ & $106.76[86.88,126.65]$ & & $\downarrow$ \\
\hline \multicolumn{9}{|c|}{$\begin{array}{l}\text { Heterogeneity: } \mathrm{Tau}^{2}=267.09 ; \mathrm{Chi}^{2}=10.73, \mathrm{df}=3(\mathrm{P}=0.01) ; \mathrm{I}^{2}=72 \% \\
\text { Test for overall effect: } \mathrm{Z}=10.52(\mathrm{P}<0.00001)\end{array}$} & $\begin{array}{ccc}-500 & -250 & 0 \\
\text { Favours [Pre] }\end{array}$ & $\begin{array}{c}250 \\
\text { Favours [Post] }\end{array}$ \\
\hline
\end{tabular}

Figure 1. Total testosterone pre- and after-surgery in patients with varicocele. $\mathrm{CI}=$ confidence interval; $\mathrm{SD}=$ standard deviation. 
Mean differences of total testosterone were statistically different in men pre- and after-surgery (mean difference $=106.76 ;[95 \%$ CI 86.88-126.65]; $p<0.0001$ ).

\section{Discussion}

Herein we demonstrated that testosterone levels pre- and after surgery were improved in all observational studies (mean difference $=106.76$; [95\% CI 86.88-126.65]; $p<0.0001$ ).

Much controversy still exists regarding the relationship between varicocele and hypogonadism. In fact, some studies reported no benefits in seminal parameters, pregnancy rates or testosterone levels in patients who underwent varicocelectomy compared to men who did not submit to surgery [26]. Therefore, this result may suggest that these men have incidental varicoceles and it is not clear whether the testicular defect is leading to abnormal spermatogenesis in these men [28].

On the other side, recent trials support the correlation between varicocelectomy and improved seminal parameters [25]. Since appropriate intratesticular testosterone levels are necessary to guarantee spermatogenesis, the investigation of Lyedig cell function is fundamental to the evaluation of infertile patients [29]. As previously stated, varicocele seems to cause pantesticular insults that lead to an impairment of both Sertoli and Leydig cell function [5]. The advancing negative repercussion of varicocele on Leydig cell function has been widely demonstrated by studies conducted on animals. For example, Luo et al. evaluated intratesticular testosterone and serum testosterone levels in 40 male SpragueDawley rats who had been previously divided into an experimental group, who underwent surgery to create a left varicocele, and a control group. Authors observed a significant decrease of intrestesticular testosterone levels 8 weeks after surgery in the experimental group $(p<0.01)$, albeit serum testosterone levels reduction was not significant $(p>0.05)$. Moreover, they registered a substantially higher mean apoptosis index of Leydig cells in the experimental group [30]. Analogously, Zheng et al. created experimental varicocele in rats and repaired it 6 weeks after induction performing ALV (artery ligating variocelectomy) or APV (artery preserving varicocelectomy). The study registered a higher testicular functionaccording to Johnsen's score-in the control group compared to the EV (experimental varicocele) and EV-ALV group and any significant difference compared to EV-APV [31].

Notwithstanding the undeniable evidence of the trials, it is important to consider the acute surgical onset of varicocele in animal studies; it is therefore uncertain if the results are translatable in human patients [32].

In conclusion, our study is not devoid of limitations. First, we predominantly analyzed retrospective, non-randomized studies that were sometimes conducted on small cohorts of patients. Second, after procedures patients were often followed up for a few months and any long-term follow up had been performed. Finally, since in some patients affected by varicocele low testosterone values were not registered, it was not possible to evaluate an effective testosterone rising after surgery had been performed.

\section{Conclusions}

The relationship between varicocele and hypogonadism becomes clearer everyday thanks to the most recent literature, particularly with regards to the impact of varicocele repair on serum testosterone levels improvement in hypogonadal patients. We reported in observational studies that testosterone levels pre- and after surgery were improved and these findings offer a new insight in this field.

It is indeed established that altered environment caused by varicocele causes pantesticular insult, but it has not been unequivocally determined whether men with varicocele are at increased risk for the development of clinical hypogonadal symptoms [33]. Moreover, since varicocele causes progressive and time-dependent testicular damage, we believe more studies should focus on pediatric population. Clearly, additional studies in larger multi-institutional cross-sections are needed to unequivocally confirm these results and to define the role of varicocelectomy. 
Author Contributions: Conceptualization, G.I.R. and S.L.V.; methodology, M.G.A.; data curation, A.E.C. and R.A.C.; writing - original draft preparation, G.I.R. and M.G.A.; writing-review and editing, S.P., R.C. and S.L.V. All authors have read and agreed to the published version of the manuscript.

Funding: This research received no external funding.

Institutional Review Board Statement: Not applicable.

Informed Consent Statement: Not applicable.

Conflicts of Interest: The authors declare no conflict of interest.

\section{References}

1. Salonia, A.; Bettocchi, C.; Boeri, L.; Capogrosso, P.; Carvalho, J.; Cilesiz, N.C.; Cocci, A.; Corona, G.; Dimitropoulos, K.; Gül, M.; et al. European Association of Urology Guidelines on Sexual and Reproductive Health-2021 Update: Male Sexual Dysfunction. Eur. Urol. 2021, 80, 333-357. [CrossRef] [PubMed]

2. Minhas, S.; Bettocchi, C.; Boeri, L.; Capogrosso, P.; Carvalho, J.; Cilesiz, N.C.; Cocci, A.; Corona, G.; Dimitropoulos, K.; Gül, M.; et al. European Association of Urology Guidelines on Male Sexual and Reproductive Health: 2021 Update on Male Infertility. Eur. Urol. 2021, 80, 603-620. [CrossRef] [PubMed]

3. Zini, A.; Alsaikhan, B.; Alrabeeah, K.; Delouya, G. Epidemiology of varicocele. Asian J. Androl. 2016, 18, 179-181. [CrossRef]

4. Baazeem, A. Varicocele: How this condition and its management affects men's health. World J. Meta-Anal. 2014, 2, 17. [CrossRef]

5. Hayden, R.P.; Tanrikut, C. Testosterone and Varicocele. Urol. Clin. N. Am. 2016, 43, 223-232. [CrossRef]

6. Dabaja, A.; Wosnitzer, M.; Goldstein, M. Varicocele and Hypogonadism. Curr. Urol. Rep. 2013, 14, 309-314. [CrossRef] [PubMed]

7. Rajfer, J.; Turner, T.T.; Rivera, F.; Howards, S.S.; Sikka, S.C. Inhibition of Testicular Testosterone Biosynthesis Following Experimental Varicocele in Rats. Biol. Reprod. 1987, 36, 933-937. [CrossRef] [PubMed]

8. Tanrikut, C.; Goldstein, M.; Rosoff, J.S.; Lee, R.K.; Nelson, C.J.; Mulhall, J.P. Varicocele as a risk factor for androgen deficiency and effect of repair. Br. J. Urol. 2011, 108, 1480-1484. [CrossRef]

9. Carrageta, D.F.; Oliveira, P.F.; Alves, M.G.; Monteiro, M.P. Obesity and male hypogonadism: Tales of a vicious cycle. Obes. Rev. 2019, 20, 1148-1158. [CrossRef]

10. Braga, P.C.; Pereira, S.C.; Ribeiro, J.C.; Sousa, M.; Monteiro, M.P.; Oliveira, P.F.; Alves, M.G. Late-onset hypogonadism and lifestyle-related metabolic disorders. Andrology 2020, 8, 1530-1538. [CrossRef]

11. Hsiao, W.; Rosoff, J.S.; Pale, J.R.; Greenwood, E.A.; Goldstein, M. Older Age Is Associated With Similar Improvements in Semen Parameters and Testosterone after Subinguinal Microsurgical Varicocelectomy. J. Urol. 2011, 185, 620-625. [CrossRef] [PubMed]

12. Gorelick, J.I.; Goldstein, M. Loss of fertility in men with varicocele. Fertil. Steril. 1993, 59, 613-616. [CrossRef]

13. Raboch, J.; Stárka, L. Hormonal Testicular Activity in Men with a Varicocele. Fertil. Steril. 1971, 22, 152-155. [CrossRef]

14. Freire, F.; Nahoum, C. Endocrine Evaluation in Infertile Men with Varicocele. Andrologia 2009, 13, 395-404. [CrossRef] [PubMed]

15. Ji, B.; Jin, X.B. Varicocele is associated with hypogonadism and impaired erectile function: A prospective comparative study. Andrologia 2017, 49, e12683. [CrossRef]

16. Weiss, D.B.; Rodriguez-Rigau, L.J.; Smith, K.D.; Steinberger, E. Leydig Cell Function in Oligospermicmen with Varicocele. J. Urol. 1978, 120, 427-430. [CrossRef]

17. Gat, Y.; Gornish, M.; Belenky, A.; Bachar, G.N. Elevation of serum testosterone and free testosterone after embolization of the internal spermatic vein for the treatment of varicocele in infertile men. Hum. Reprod. 2004, 19, 2303-2306. [CrossRef]

18. Hsiao, W.; Rosoff, J.S.; Pale, J.R.; Powell, J.L.; Goldstein, M. Varicocelectomy is associated with increases in serum testos-terone independent of clinical grade. Urology 2013, 81, 1213-1217. [CrossRef]

19. Andò, S.; Giacchetto, C.; Colpi, G.; Beraldi, E.; Panno, M.L.; Lombardi, A.; Sposato, A.G. Physiopathologic Aspects of Leydig Cell Function in Varicocele Patients. J. Androl. 1984, 5, 163-169. [CrossRef]

20. Srini, V.S.; Veerachari, S.B. Does Varicocelectomy Improve Gonadal Function in Men with Hypogonadism and Infertility? Analysis of a Prospective Study. Int. J. Endocrinol. 2011, 2011, 1-6. [CrossRef]

21. Zohdy, W.; Ghazi, S.; Arafa, M. Impact of Varicocelectomy on Gonadal and Erectile Functions in Men with Hypogonadism and Infertility. J. Sex. Med. 2011, 8, 885-893. [CrossRef] [PubMed]

22. Abdel-Meguid, T.A.; Farsi, H.M.; Al-Sayyad, A.; Tayib, A.; Mosli, H.A.; Halawani, A.H. Effects of Varicocele on Serum Testosterone and Changes of Testosterone After Varicocelectomy: A Prospective Controlled Study. Urology 2014, 84, 1081-1087. [CrossRef]

23. Panach-Navarrete, J.; Morales-Giraldo, A.; Ferrandis-Cortés, C.; García-Morata, F.; Pastor-Lence, J.C.; Martínez-Jabaloyas, J.M. Is there a relationship between varicocele and testosterone levels? Aging Male 2020, 23, 592-598. [CrossRef] [PubMed]

24. Pasqualini, T.; Chemes, H.; Coco, R.; Domené, H.; Campo, S.; Nicolau, G.; Lavieri, J.; Rivarola, M.A. Testicular Function in Varicocele. Int. J. Androl. 1980, 3, 679-691. [CrossRef]

25. Saylam, B.; Çayan, S.; Akbay, E. Effect of microsurgical varicocele repair on sexual functions and testosterone in hy-pogonadal infertile men with varicocele. Aging Male 2020, 23, 1366-1373. [CrossRef] [PubMed]

26. Whelan, P.; Levine, L. Effects of varicocelectomy on serum testosterone. Transl. Androl. Urol. 2016, 5, 866-876. [CrossRef]

27. Fisch, H.; Hyun, G. Varicocele repair for low testosterone. Curr. Opin. Urol. 2012, 22, 495-498. [CrossRef] [PubMed]

28. Wallach, E.E.; Hudson, R.W. The endocrinology of varicoceles. Fertil. Steril. 1988, 49, 199-208. [CrossRef] 
29. Wallach, E.; Steinberger, E. The Etiology and Pathophysiology of Testicular Dysfunction in Man. Fertil. Steril. 1978, $29,481-491$. [CrossRef]

30. Luo, D.-Y.; Yang, G.; Liu, J.-J.; Yang, Y.-R.; Dong, Q. Effects of varicocele on testosterone, apoptosis and expression of StAR mRNA in rat Leydig cells. Asian J. Androl. 2010, 13, 287-291. [CrossRef]

31. Zheng, Y.-Q.; Zhang, X.-B.; Zhou, J.-Q.; Cheng, F.; Rao, T.; Yao, Y. The Effects of Artery-Ligating and Artery-Preserving Varicocelectomy on the Ipsilateral Testes in Rats. Urology 2008, 72, 1179-1184. [CrossRef] [PubMed]

32. Schlegel, P.N.; Goldstein, M. Alternate indications for varicocele repair: Non-obstructive azoospermia, pain, androgen deficiency and progressive testicular dysfunction. Fertil. Steril. 2011, 96, 1288-1293. [CrossRef] [PubMed]

33. La Vignera, S.; Izzo, G.; Emerenziani, G.P.; Cannarella, R.; A Condorelli, R.; E Calogero, A.; Aversa, A. Male hypogonadism: Therapeutic choices and pharmacological management. Minerva Endocrinol. 2020, 45, 189-203. [CrossRef] [PubMed] 